\title{
INNOVATION PROJECT MACHINE IN A SYSTEMS APPROACH TO ENGINEERING MANAGEMENT
}

\author{
Iwona Lapunka, ${ }^{1}$ Dominika Jagoda-Sobalak, ${ }^{2}$ Katarzyna Marek-Kolodziej ${ }^{3}$
}

\begin{abstract}
In recent years, the project approach has become an increasingly popular tool for achieving operational and strategic goals and to generally advance the business activity of organizations in fields such as innovation management. We demonstrate the need of including the project approach in the processes of creating innovative solutions. We posit that these two work methods can be combined into a coherent approach known as the innovation project machine. As part of this approach, innovations are implemented and developed more effectively, while agile project management and consolidated research for project managers, amongst others, are the source of inspiration. A systems approach to this concept could constitute a coherent synthesis of solutions available for engineering management. A proposition to integrate the project approach with innovative processes will enable expedient execution of business strategies in contemporary companies.
\end{abstract}

JEL Classification Numbers: L20, O30; DOI: http://dx.doi.org/10.12955/cbup.v5.936

UDC Classification: 658:005.4

Keywords: innovation, project management, engineering management, market-pull innovation, user-driven innovation.

\section{Introduction}

The rapidly increasing participation of developing countries in the global production industry impels Western European economies to undertake steps aimed at improving the competitiveness of factories who have thus far been operating in local markets. Industry 4.0 (German: Industrie 4.0), a program initiated in Germany, and promoted in other countries, is meant to drive a fourth industrial revolution. Poland, together with other Central and Eastern European countries of considerable industrial traditions, are becoming competitive not only due to low work costs. An increasing number of modern factories are being built in these countries, which, owing to the employed technologies, enable a rapid development of business with substantial added value. In this respect, the global concept of engineering of the future is in line with the ideas and assumptions of the Industry 4.0 program - it evolves towards innovative, adaptive, and intelligent technologies and industrial processes.

The transformation of economic focus from production to market forced entrepreneurs to look for new ways of developing and maintaining their position in the market of goods and services. In industrial practice, we observe a systematic evolution of the fundamental sources of competitive advantage (cf. Table 1). Innovations in companies are directed at implementing changes that lead to an increase in the modernity and competitiveness of a company, its development, and in consequence, boosting its value.

\begin{tabular}{|l|l|l|l|}
\hline Table 1: Evolution of fundamental sources of competitive advantage \\
\hline \multicolumn{1}{|c|}{ Period } & \multicolumn{1}{|c|}{ Motivation } & \multicolumn{1}{c|}{ Advantage } & \multicolumn{1}{c|}{ Features } \\
\hline 1960 s and 70s & $\begin{array}{l}\text { cheaper production of } \\
\text { goods and services }\end{array}$ & lower costs & $\begin{array}{l}\text { work division, make-to-stock } \\
\text { (MTS), mass production }\end{array}$ \\
\hline 1980 s and 90s & $\begin{array}{l}\text { better production of } \\
\text { goods and services }\end{array}$ & $\begin{array}{l}\text { higher quality and } \\
\text { speed }\end{array}$ & $\begin{array}{l}\text { lean production and } \\
\text { management, just-in-time (JIT), } \\
\text { flexible specialization }\end{array}$ \\
\hline Post 2000 & $\begin{array}{l}\text { better goods and } \\
\text { services, saving the } \\
\text { environment }\end{array}$ & $\begin{array}{l}\text { aesthetics, authenticity, } \\
\text { sustained development }\end{array}$ & $\begin{array}{l}\text { refined design, innovations, } \\
\text { uniqueness, decreasing human } \\
\text { impact on environment }\end{array}$ \\
\hline
\end{tabular}

Innovation processes have become an inherent part of contemporary engineering management. Currently they constitute one of the foundations of managing technical functions, in particular: research, design, production, and in the strategic dimension in the areas of managing development projects, as well as production and services companies. This managing is carried out in the context of

\footnotetext{
${ }^{1}$ Opole University of Technology, Faculty of Production Engineering and Logistics, i.lapunka@po.opole.pl

${ }^{2}$ Opole University of Technology, Faculty of Production Engineering and Logistics, d.jagoda@ po.opole.pl

${ }^{3}$ Opole University of Technology, Faculty of Production Engineering and Logistics, k.marek-kolodziej@po.opole.pl
} 
fierce market competition, high technology and under the conditions of rapid changes to production and operation techniques. The approach to innovations and the means of creating them in companies undergo continual changes too. These changes are a direct consequence of the arrival of new concepts and methods that tackle the creation of innovations in an increasingly comprehensive manner, especially at the level of production and in services companies. Contemporary processes of creating and implementing innovations require appropriate competences and knowledge founded on project management principles (Karbownik, 2005; Kisielnicki, 2013).

\section{Engineering management paradigm in contemporary science}

Engineering (Latin: ingenium, i.e., inventiveness) defined as 'broadly understood theory and practice of cognition, as well as deliberate influence and control over a process or system' (Słowiński, 2009) reflects the contemporary development of directions of production. It is concomitant of a particular way of thinking oriented at streamlining processes that can result in a new product or a process closer to ideal than its predecessor. Its aim is to integrate information resources, design, production and control processes, transportation, and storage processes into a unified, comprehensively managed manufacturing process (Komitet Inżynierii Produkcji PAN, 2010). In this respect, a key role is played by engineering management, often identified with production management or managing a production workshop or plant. However, under the conditions of modern manufacturing technique, engineering management is usually understood as (Durlik, 1996):

- managing technical functions, such as: research, design, production (present in every company in which modern technologies are employed),

- managing more broadly understood functions, such as: marketing, manufacturing goods and services, distribution and trading, as well as managing development projects and manufacturing companies at higher levels, when the managing is carried out in the context of market competition, high technology and under the conditions of rapid changes to production and operation techniques.

Theoretical foundations of engineering management can be found in the school of scientific work organization (1890s-1930s), commonly known as scientific management or Taylorism, after its founder. Its aim was to find the best method to accomplish any task as well as to select, train, and motivate workers. Representatives of this trend include Frederick W. Taylor, Henry L. Gantt, Karol Adamiecki, and Frank and Lillian Gilbreth (Koźmiński and Piotrowski, 1998).

At the turn of the 19th and 20th centuries, in researching and optimizing workers' productivity, Taylor noticed that every piece of work can be divided and subdivided into smaller elements, down to individual movements. In 1903 Gantt worked out a method for graphically representing many different activities performed over different times, comprising a complex enterprise. In 1896 a method similar to the Gantt chart was presented by Adamiecki, a Polish founder of the science of organization and management, and the inventor of chronoanalysis.

Scientific management has introduced scientific approaches for solving operational problems into industrial engineering. Over the years, the assortment of available technologies has increased, and simultaneously new trends in the science of organization and management have developed. Industrial engineering has become increasingly focused on process, defined as an organized sequence of human activities transforming resources into goods and services, abstracted to a degree, from the facet of physical and chemical detail. Gradually, a new dimension of engineering has entered the picture production for profit. The product of industrial execution processes, resulting from technical thinking, is not manufactured for its own sake. Rather, it is the outcome of specific market expectations, incurred costs, fierce competition, and other economic factors playing part in the transformation of an idea into a product and selling it.

At present, a noticeable market trend is end-to-end product management, i.e., generating the requirements for a new product from the stages of design and test production, through market introduction and distribution, to withdrawing the product from the market and replacing it with a new version or a new product. This demonstrates the need for radical market transformations and innovative changes towards the integration of the processes of creating innovation and managing projects. 


\section{Particulars of executing innovation projects}

Projects have become the main driving force of social development. Today, the methods for conducting projects used and disseminated by various organizations are mostly based on collections of good practices. Innovation projects have a special place among all enterprises. Companies perceive them as an opportunity to increase their competitive advantage, whereas the European Union has designated them to be the central theme of Horizon 2020, a program for financing research and innovation. Considering the specificity of innovation, the turbulent contemporary environment and the high risk of failure of innovation projects, it was recognized that the current, classical approach to managing innovation projects is insufficient (Spałek, 2016).

According to some authors the recent focus of science on human capital is also based on assumptions resulting from best practices, and therefore it should not be expected to significantly improve project processes. B. Lent sees the role of feedback as a basis for conducting projects, which could become the foundation of theoretical studies (Lent, 2012). The understanding of rules and mechanisms of feedback should lead to an expected significant increase in the effectiveness of executed projects. His rationalist theory is based on Wiener's (1961) and von Foerster's (1974) systems cybernetics, which Lent augments with the thir d degree cybernetic feedback in the project manager's decision process.

Modern approaches to project management (agile, soft, and lightweight methodologies) (Wirkus et al., 2014) elaborated over the last two decades, constitute a group of alternative approaches to conducting IT projects. These approaches are increasingly applied to managing other types of projects, and innovation projects in particular. To a large extent, these approaches are based on adaptive, agile, and lean management, progressing towards a unified, strategic framework of AgiLean PM projects (Demir, 2013). Somewhat paradoxically, in innovation project management there exists a strong need for employing routine actions alongside new competencies (Czakon, 2012).

\section{Project approach as support for creating market-pull innovations}

New trends in innovativeness pertain both to creating goods and services (research and development $\mathrm{R} \& \mathrm{D}$, user-driven innovation), and to the changes within the structure of a company (organizational and marketing innovation). New forms of innovation (non-technological, user-driven, open, and social) require business entities to display new skills as well as to conduct an active policy that will stimulate the creation of such innovations in companies (Szymańska, 2012).

Particularly worth noting are the benefits of user-driven innovation (UDI). Progressing globalization processes have a direct impact on the increasing importance of consumers, understood not only as purchasers, but also as co-creators of goods and services. As a result, production and services are better suited to the expectations of the end user, while at the same time the costs of innovation are reduced. UDI is a method of implementing innovation focused on creating new ideas and solutions based on consumers' knowledge and needs. In other methods of implementing innovation, the consumers' knowledge is used mainly to assess existing solutions.

User-driven innovation is based on a more thorough understanding of both the explicit and implicit needs of consumers, their expectations and requirements. It consists in acquiring and using information, ideas and ready-made solutions proposed by consumers. User-driven innovation is poised to become the second pillar of programs supporting innovative businesses, alongside technological innovation. In general, there are two main perspectives on user-driven innovation: the voice of the customer perspective, and the lead-user innovation perspective (cf. Table 2). These two 'schools of thought' are borne out of the academic research and practical experiences of David Kelley, Tim Brown and Eric von Hippel (among many others) (Nordic Council of Ministers, 2006).

It is assumed that the business activity of companies in the scope of $\mathrm{R} \& \mathrm{D}$, with active cooperation on the part of consumers (user-driven innovation), can be treated as a specific innovation project serving the effective execution of strategic business goals of a company. Initiated in the scope of $R \& D$, gradually laid out and expanded in terms of results, such a project requires project-oriented management. The management model for $R \& D$ processes is reflected in project management methodologies. Classical methodological approaches reflect the philosophy and organization of project processes in the form of waterfall models, driven by the principle 'plan first to avoid change'. In the waterfall model, it is assumed that precisely defined stages follow in succession, always in the same order. In $R \& D$ processes, this is possible when actions are executed in the scope of fundamental and 
applied research. The strategy of implementing solutions within such a model is currently termed market-push strategy.

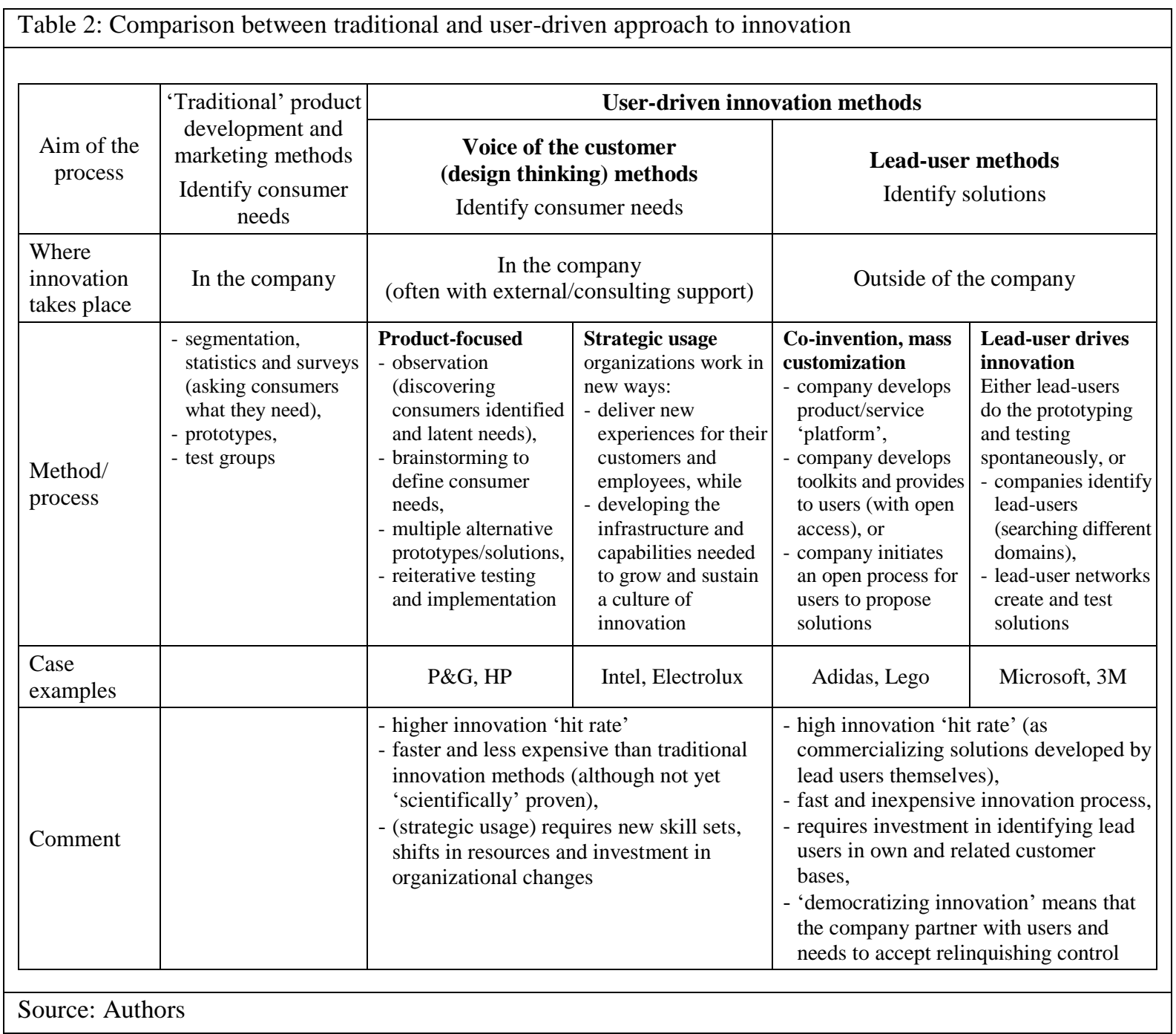

Developmental works, on the other hand, based on information processing so as to adjust the developmental process to the changing environment (e.g., target market for developed goods and services), necessitate an agile and adaptive approach to management. They are driven by a different principle - 'implement incrementally to manage change.' Efficiency, flexibility and rapid pace are among the most significant features of the agile approach to user-driven innovation (Abbas, Gravell, Wills, 2008). These result from self-organization, adaptability, radical shortening of the development cycle, the introduction of control events ensuring the high incidence of customer or end user feedback, as well as other elements comprising the internal and external project environment.

The unpredictable and unique nature of innovation projects in $R \& D$ is a consequence of the marketpull strategy. Innovation projects are characterized by an element of uncertainty as to the course of the project and thus to its future result. As a general rule, at the outset of such projects, only the general aim is known, while the exact course of action is adjusted on the fly, in close cooperation with users/consumers.

\section{Innovation project machine in a systems approach to engineering management}

Popular innovation management models generally operate according to a similar formula: strategycreativity-execution. The innovation process itself is typically analyzed along three dimensions: inspiration, ideation, and implementation. The latter two can be compared to two major stages of project management, i.e., planning and execution. In the project approach, ideation as a process of forming and developing new ideas concerns initiating, defining, and planning innovation projects. Implementation, in turn, involves the execution of projects. Therefore, a fundamental question that we 
ask here is: why should the methods of working with ideation and implementation in innovation process be any different from the methods for enabling efficient project execution? Arguments presented in this article indicate that these two work methods can be integrated into a coherent approach, termed an innovation project machine (Vedsmand, 2013). Within the scope of this approach, innovations are implemented more effectively, while inspiration is drawn, among others, from agile project management methods and established knowledge for project managers. Innovation project machine proposes a coherent synthesis of solutions available as part of engineering management for processes, projects and innovation (cf. Figure 1).

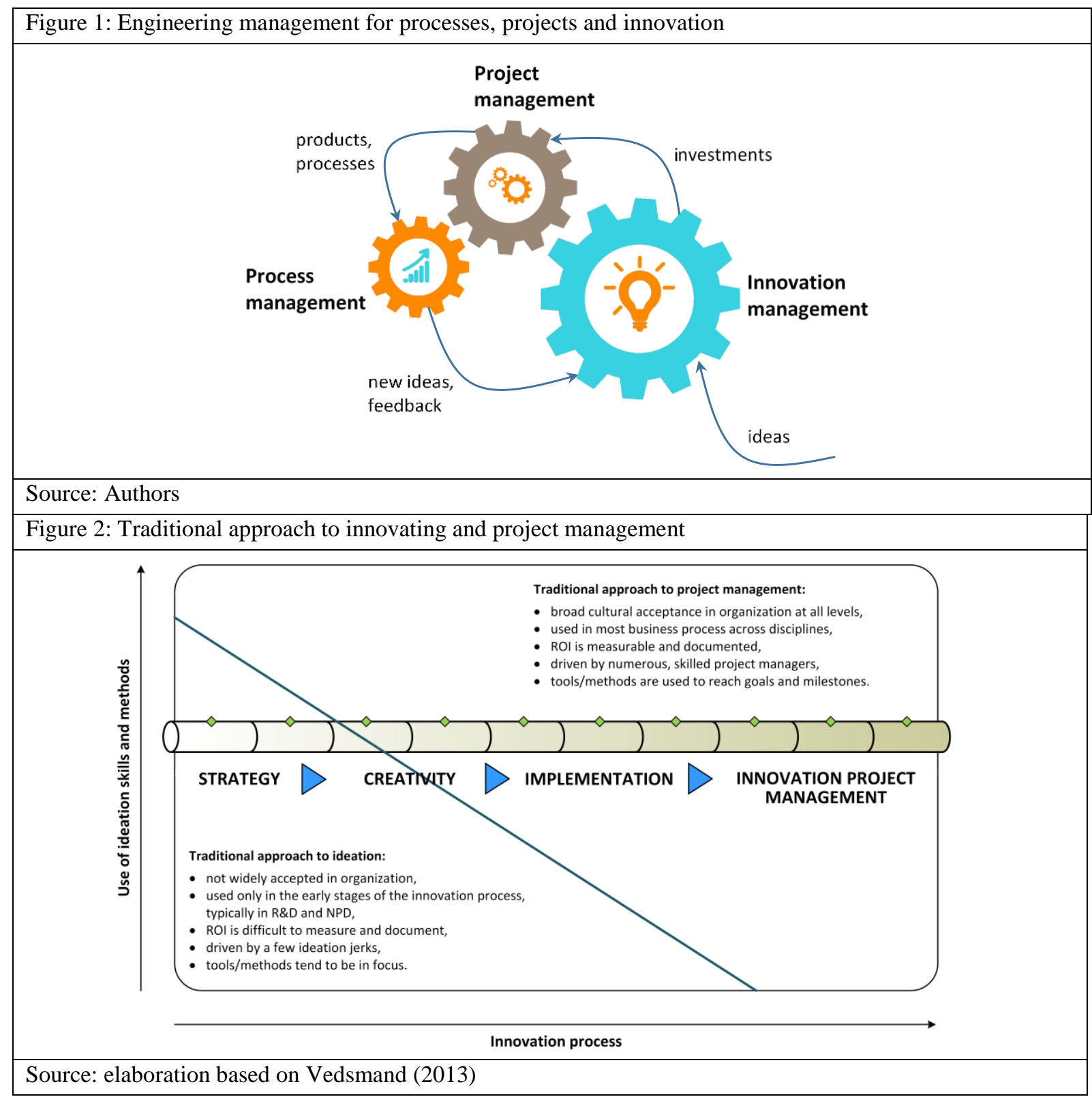

Project managers responsible for generating ideas often approach this project stage somewhat condescendingly, and as a result their true engagement materializes too late. Despite generating many attractive ideas inspired by creative processes, as a general rule, ideas that lack specified execution models and/or clearly defined vision are rejected. The majority of managers, even the experienced ones, are reluctant to undertake challenges that carry a significant risk. Poor acceptance for generated ideas is one of many problems faced by the traditional approach to innovating (cf. Figure 2). Moreover, compared with other stages in a project lifecycle, such activities are not given sufficiently high priority. Similar observations apply to innovation projects, which in general are less prone to be selected for execution compared with other projects. In this respect, lower risk and established managerial know-how significantly increase the chances of success. Without doubt, the roles of the 
innovator and that of a project manager have to be distinguished here, as in a traditional approach, their competences do not overlap.

Innovation projects stand out mostly due to the nature of creating and developing ideas. They cannot directly enter the first or second phase of a stage-gate process, since their end result is often underspecified, and the initial concept itself requires incubation. Innovation projects are hard to assess through standard criteria, such as time-to-market or fitness to strategy. This fuels the negative perception and reluctance of companies to engage in innovative activities. Still, the introduction of innovation through a project has the potential to cause significant changes to a company and its market position. Traditional approaches to innovating and project management, presented in Fig. 2, are two separate branches of idea development. Each of them is in a way responsible for obtaining suboptimal results, despite their strong points in terms of, respectively, creating or executing innovative solutions.

Streamlining the innovation process does not necessarily involve designing completely new formulas. It is possible to re-use the solutions that are employed and perform well in project execution. Rather, it is the tools and methods for aiding creative processes that require integration with project processes, so as to comprise a coherent system which will play a pivotal role in increasing the effectiveness of conducting innovation projects. The concept realized through such integration was proposed by Vedsmand and is termed innovation project machine (cf. Figure 3).

Figure 3: New innovation process integrating the best practices of creating innovation and project management

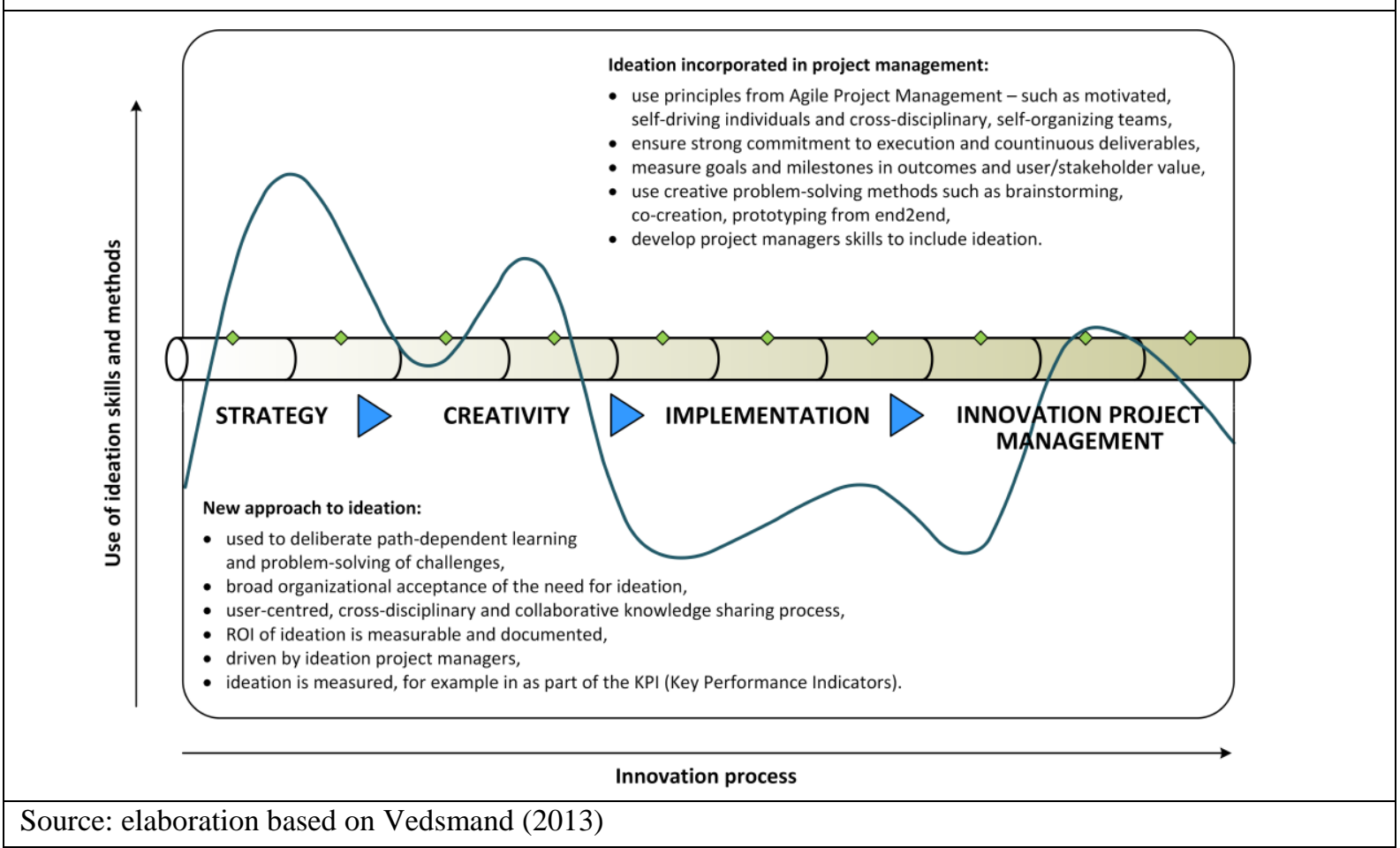

\section{Summary}

Engineering management as a dynamic field develops by adjusting to the needs of economy and continually strives to improve organizational processes and increase production efficacy. Over the last years, the shift in economic orientation from production to market-based forced entrepreneurs to seek new methods of development and to stay afloat on the market of goods and services. Increasing uncertainty due to rapid changes necessitated the creation and implementation of new approaches to organizing processes and production systems in almost every branch of industry. An appropriate reaction to the dynamic needs of economy is a sign of the modern times. In the 21 st Century, the concept of innovation project management has gained particular importance in the face of the challenges faced by contemporary organizations. Traditional management methods oriented at the harmonization of simple and unrepeatable activities turn out to be insufficient for continually changing situations; however, they offer stability. Management focused on simple and repeatable activities gives way to complex and unrepeatable management, carried out in a turbulent world (Kisielnicki, 2013). 
Innovation has become one of the major elements of knowledge-based economy and keeps acquiring strategic importance in the context of generating economic growth, which translates into social prosperity. Up to a quarter of a century ago, Drucker already stated that 'a company unable to create innovation dies' (Drucker, 1990). According to experts, due to the increasing pressure of competition in the modern world, the ability to create innovation becomes one of the key factors determining the developmental potential of companies. Customers and consumers increasingly often take part in creating innovation. The most modern of currently known innovation implementation methods, oriented at creating innovative solutions based on consumers' needs, is user-driven innovation or UDI. Simultaneously, the need to include the project approach in the creation of innovative solutions is acknowledged.

The evolution of innovation project management practices indicates the need to redefine numerous areas of the project approach, to adapt to transformations in the environment, and to shift in the direction of project-based and knowledge-based organizations. Eschewing traditional management concepts for their project-oriented counterparts, while taking into account lean and agile strategies; noticing the opportunities and risks of undertaken projects; feedback in the decision processes; developing soft aspects, such as: a proper conglomeration of competences of project teams, high intellectual capital, precise communication, and project knowledge management - all constitute current trends in innovation project management.

The concept of innovation project machine presented in the article paves the way for future studies and could inspire a more in-depth exploration of the presented issues and attempts to fill research gaps in the proposition of systems approach to engineering management of processes, projects, and innovations. The continued search for sources, obstacles and processes related to including innovation creation in project management is an essential element of developing new principles in systems engineering management.

\section{References}

Abbas, N., Gravell, A.M. \& Wills, G.B. (2008). Historical roots of agile methods: where did 'agile thinking' come from? Agile Processes in Software Engineering and Extreme Programming, Lecture Notes in Business Information Processing, 9, 94-103.

Burzyński, W. (2008). Popytowe podejście do innowacji (user-driven innovation) jako czynnik sukcesu w korzystaniu z funduszy unijnych [User-driven innovation as a factor in the success of using EU funds]. [in:] Horodyńska, E. (Ed.), Tendencje innowacyjnego rozwoju polskich przedsiębiorstw [Trends of innovative development of Polish enterprises]. Warszawa: Instytut Wiedzy i Innowacji (in Polish).

Czakon, W. (2012). Równowaga a wzrost - relacja odwróconego U w naukach o zarządzaniu [Equilibrium and growth U reverse relation in management sciences]. Przegląd Organizacji, 10, 7-10 (in Polish).

Demir, S.T. (2013). AgiLean PM - a unifying strategic framework to manage construction projects. Liverpool: Liverpool John Moores University.

Drucker, P.F. (1990). Managing the non profit organisation: principles and practices. New York: Harper Collins.

Durlik, I. (1996). Inżynieria zarządzania. Strategia i projektowanie systemów produkcyjnych [Engineering management. Strategy and design of production systems]. Parts I-II. Warszawa: Agencja Wydawnicza Placet (in Polish).

Karbownik, A. (2005). Problemy w zarządzaniu projektami w przedsiębiorstwie [Problems managing projects in an enterprise]. Zeszyty Naukowe Politechniki Śląskiej, Organizacja i Zarządzanie, 26, Gliwice: Wydawnictwo Politechniki Śląskiej (in Polish).

Kisielnicki, J. (2013). Zarządzanie projektami badawczo-rozwojowymi [Management of R\&D projects]. Warszawa: Oficyna a Wolters Kluwer business (in Polish).

Komitet Inżynierii Produkcji PAN (2010). Stan i perspektywy badań naukowych w obszarze inżynierii produkcji w Polsce [State and perspectives of research in the field of production engineering in Poland]. Warszawa (in Polish).

Koźmiński, A.K. \& Piotrowski, W. (1998). Zarządzanie. Teoria i praktyka [Management. Theory and practice]. Warszawa: Wydawnictwo Naukowe PWN (in Polish).

Lent, B. (2012). A contribution towards the theory of the project management. Zeszyty Naukowe AON, 1 (86), 263-277.

Nordic Council of Ministers (2006). Understanding user-driven innovation. Copenhagen: Norden.

Słowiński, B. (2009). Inżynieria zarządzania procesami logistycznymi [Engineering management of logistics processes]. Koszalin: Wydawnictwo Uczelniane Politechniki Koszalińskiej (in Polish).

Spałek, S. (2016). Projekty innowacyjne. Istota i uwarunkowania [Innovation projects - the idea and determinants]. Nauki o Zarządzaniu, Management Sciences, 1 (26), Wrocław: Wydawnictwo Uniwersytetu Ekonomicznego we Wrocławiu, 132141 (in Polish). 
Szymańska, A.I. (2012). Wpływ innowacyjności na konkurencyjność przedsiębiorstw [Impact of innovation on the competitiveness of enterprises]. [in:] Stabryła, A., Małkus, T. (Eds.), Strategie rozwoju organizacji [Organization development strategies]. Encyklopedia Zarządzania, Kraków: Mfiles.pl, 183-197 (in Polish).

Vedsmand, T. (2013). Making ideation a part of the 'innovation project machine'. Retrieved from $\mathrm{http} / / / \mathrm{www}$. innovationmanagement.se, (available online: 28.09.2015).

von Foerster, H. (Ed.) (1974). Cybernetics of cybernetics, biological computer laboratory. Urbana-Champaign: University of Illinois.

Wiener, N. (1961). Cybernetics or control and communication in the animal and the machine. Second Edition. Cambridge: The MIT Press.

Wirkus, M., Roszkowski, H., Dostatni, E. \& Gierulski, W. (2014). Zarządzanie projektem [Project management]. Warszawa: PWE (in Polish). 